
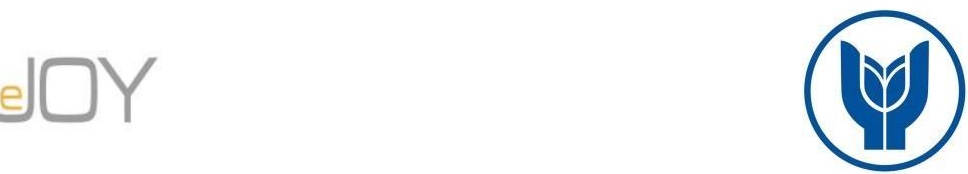

Special Issue on 3rd International EUREFE Congress

\title{
Kümelenme Potansiyelinin Belirlenmesi: TR32 Bölgesi İmalat Sektörlerinde Bir Uygulama
}

\section{Determination of Clustering Potential: An Application in Manufacturing Sector of TR32 Region}

\author{
Zekiye ÇAMLICA, Aydın Menderes Üniversitesi, Türkiye, zcamlica@gmail.com \\ Orcid No: 0000-0001-8901-8394 \\ Hüseyin ŞENKAYAS, Aydın Menderes Üniversitesi, Türkiye, senkayas@gmail.com \\ Orcid No: 0000-0002-9533-9853
}

Öz: Bölgesel kalkınma, belli bir coğrafi alanın gelişmişlik düzeyini arttıracak sosyo-ekonomik faaliyetlerin tamamını kapsamaktadır. Günümüz koşullarında ülkelerin zaman zaman karşı karşıya kaldıkları ekonomik daralma ve darboğazlardan korunmasının en önemli yolunun katma değerli ürünlerin içsel kaynaklara dayalı olarak üretilebilmesi olduğu söylenebilir. Bu yaklaşımdan doğan kümelenme kavramı tüm dünyada kabul görmüş, Türkiye'de son dönem kalkinma stratejileri içinde kendine önemli ölçüde yer bulmuştur. Bölgesel kalkınmanin en güçlü araçlarından biri olan kümelenme, aralarında dikey ve yatay ilişski ve işbirliği ağları bulunan işletmeler ile Kaтu Kurumları, Ticaret ve Sanayi Odaları, Sivil Toplum Kuruluşları gibi destek kuruluşları ve Üniversiteler, Ar-Ge Merkezleri gibi eğitim ve araştırma kurumlarının sektör ve coğrafi konum bazında yoğunlaşması olarak tanımlanabilir. Bölge ekonomisine katkıda bulunması yanında sektörel gelişme ve işletme performansı açısından çok yönlü faydalar sağlayan kümelenme pek çok kaynaktan teşvik edilmektedir. Bu kapsamda dünyada ve ülkemizde yürütülmüss ve yürütülmekte olan birçok proje bulunmaktadır. Kümelenmenin gelişstirilmesi için yürütülecek faaliyetlerin amacına ulaşabilmesi için öncelikle bölgedeki kümelenme potansiyeli yüksek sektörlerin doğru seçilmiş olması gerekir. Aydın, Denizli ve Muğla illerini kapsayan TR32 bölgesinde kümelenme faaliyetleri için uygun olabilecek sektörlerin belirlenmesi bu çalışmanın temel amacinı oluşturmaktadır. İmalat sektörlerini esas alan çalışmada istihdam verileri kullanilarak uygulanan analizlerle öncelikle sektörel yoğunlaşmalar saptanmış, sonrasında sektörlerin rekabet gücü irdelenmiştir. Sektörel yoğunlaşmaların saptanmasında Location Quotient (Bölgesel Yoğunlaşma), rekabet gücü yüksek sektörlerin belirlenmesinde ise Shift Share (Değişim Payl) analizlerinden faydalanılmıştır. Belli bir dönem içinde bölgedeki sektörel yoğunlaşmalarda meydana gelen değişimin büyüklüğ̈̈ ve yönü dikkate alınarak yapılan değerlendirme ile sektörlerin doğru konumlandırllabilmesi mümkün olmaktadır. Araştırma bulguları doğrultusunda TR32 bölgesi illerinde kümelenme faaliyetleri için uygun bulunan sektörler önerilmiştir.

Anahtar Kelimeler: Bölgesel Kalkinma, Kümelenme, TR32 Bölgesi, Location Quotient, Shift Share

JEL Siniflandırmast: O25, R12, R58

Abstract: Regional development covers all socio-economic activities that will increase the level of development of a certain geographical area. In today's conditions, the most important way of protecting countries from the economic contraction and bottlenecks they face from time to time is to produce value-added products based on 
Çamlıca, Z., Şenkayas, H. / Journal of Yasar University, 2020, Special Issue on 3rd International EUREFE Congress, 88-105

internal resources. The clustering concept arising from this approach is recognized throughout the world and has been involved significantly in the last term development strategy in Turkey. Clustering, that is one of the most powerful tools of regional development, can be defined as the sectoral and geographical concentration of enterprises and institutions (Public Institutions, Chambers of Commerce and Industry, Non-Governmental Organizations and educational and research institutions such as Universities and $R \& D$ Centers) which have vertical, horizontal relations and cooperation networks. In addition to contributing to the regional economy, the clustering, which provides multifarious benefits in terms of sectoral development and business performance, is encouraged from many sources. Within this scope, there are many projects carried out in the world and in our country. In order to achieve the purpose of the activities for the development of the cluster, the sectors with high clustering potential in the region must be selected correctly. The main objective of this study is to identify the sectors that may be suitable for clustering activities in the TR32 region covering Aydin, Denizli and Muğla. In this study, which is based on manufacturing sectors, sectoral concentrations were determined firstly with the analyzes applied using employment data and then the competitiveness of the sectors was examined. Location Quotient was used to determine sectoral concentrations and Shift Share analyzes were used to identify highly competitive sectors. It is possible to determine the sectors correctly by taking into consideration the magnitude and direction of the change in the sectoral concentrations in the region within a certain period. In the light of the findings of the research, sectors which are suitable for clustering activities in TR32 region provinces have been proposed.

Keywords: Regional Development, Clustering, TR32 Region, Location Quotient, Shift Share

JEL Classification: O25, R12, R58

\section{Giriș}

Kalkınma geçmişten bugüne ulusların temel önceliklerinden olmayı sürdürmektedir. Kendi kaynaklarını kullanarak yarattıkları ekonomik büyümenin gelişmişlik düzeyi ve toplumsal refah üzerindeki olumlu etkileri ülkelerin varlık ve bütünlüğünün korunmasındaki temel unsurlardandır. Kalkınmanın bölgesel dinamikler doğrultusunda planlanması gereği "Bölgesel Kalkınma" kavramını ortaya çıkarmıştır. Bölgesel Kalkınma belli bir coğrafi alandaki gelişmişlik düzeyini arttırıcı tüm sosyo-ekonomik faaliyetler bölgesel kalkınma kapsamında değerlendirilebilir. $\mathrm{Bu}$ bağlamda, bölge ekonomisine katkıda bulunması yanında sektörel gelişme ve işletme performansı açısından çok yönlü faydalar sağlayan "Kümelenme” bölgesel kalkınmada kullanılan en güçlü araçlardan biri olarak karşımıza çıkmaktadır. Kümelenme yaklaşımı, dünya genelindeki pek çok ülkede olduğu gibi ülkemizde de benimsenmekte ve kümelenme faaliyetleri çeşitli kaynaklardan teşvik edilmektedir. Kümelenme desteklerinin amacına ulaşabilmesi için faaliyetlerin yürütüleceği alanların seçimi büyük önem taşımakta, faaliyetlerin doğru planlanabilmesi için öncelikle ilgili bölgelerde kümelenme potansiyeli yüksek sektörlerinin belirlenmesine yönelik sağlıklı araştırmaların yapılmasına ihtiyaç duyulmaktadır. Ülkemizdeki kümelenme çalışmalarında henüz tatmin edici düzeylere 
Çamlıca, Z., Şenkayas, H. / Journal of Yasar University, 2020, Special Issue on 3rd International EUREFE Congress, $88-105$

ulaşılamamış olması konuyla ilgili araştırmaların önemini ve bu araştırmalara duyulan ihtiyacı ortaya koymaktadır.

Konuyu Aydın, Denizli ve Muğla illerini kapsayan TR32 bölgesi açısından ele alan bu çalışma, bölge illerinde kümelenmeye uygun sektörlerin belirlenmesini ve bu bağlamda bölge illeri için planlanması muhtemel kümelenme çalışmalarına ışık tutmayı amaçlamaktadır. Çalışmada öncelikle kavramsal çerçeveye yer verilmiş, uygulama kısmında ise bölge illerinin kümelenme potansiyeli, imalat sektörleri esas alınarak analiz edilmiştir. İstihdam verileri kullanılarak uygulanan analizlerle sektörel yoğunlaşmalar ve sektörlerin rekabet gücü ortaya konmuş, araştırma bulguları doğrultusunda TR32 bölgesi illerinde kümelenme faaliyetleri için uygun olabilecek sektörler belirlenmiş ve önerilmiştir.

\section{Kavramsal Çerçeve}

\subsection{Bölgesel Kalkınma ve Kümelenme}

Ülkelerin varlıklarını sürdürebilmesi ve toplumsal refahın sağlanabilmesinde ekonomik büyüme ve kalkınma önemli bir role sahiptir. Kalkınma, ülke ekonomisindeki sürekli ve sağlıklı büyümenin doğurduğu milli gelir artışının ekonomi ve sosyo-kültürel yapı üzerindeki olumlu etkilerini kapsayan bir süreç olarak tanımlanabilir. Ülkenin var olan kaynak ve olanaklarının verimli ve etkili biçimde kullanılması kalkınmanın sağlanabilmesindeki temel ilkedir (Arslan, 2005, s. 276). Kalkınma, devlet, iş dünyası ve vatandaşların ortak çabaları ile gerçekleştirilebilir. Ancak, sağlıklı kalkınmadan söz edebilmek için elde edilen faydalardan tüm paydaşların ortak pay alabilmesi sağlanmalıdır.

Kalkınma bölge bazında ele alındığında "bölgesel kalkınma" kavramı ortaya çıkmaktadır. Kalkınmanın bölgelerin özellikleri, ağırlıklı sektörleri, ihtiyaç ve olanakları değerlendirilerek bölgeler özelinde planlanması faaliyetlerin daha etkili bir biçimde yürütülmesine ve geliştirilmesine olanak vermektedir.

Bölgesel Kalkınma araçlarının en önemlilerinden biri olan Kümelenme, belli bir coğrafi bölgede yoğunlaşmış, ortak bir sektör için faaliyet gösteren, aralarında bağlantı ve ilişki ağları bulunan firma, kurum ve kuruluşların oluşturduğu endüstriyel yapıyı ifade etmek için kullanılır. Kümelenme, bölgesel ve ulusal rekabet avantajı yaratmak, ekonomik ve sosyal açıdan bölgesel gelişime katkı yapmak, iş birliği, bilgi birikimi, sosyal kapital ve inovasyonu geliştirerek işletmelerin performansını arttırmak gibi yönleriyle öne çıkan bir modeldir. 
Kümelenmeler, aynı zamanda hem rekabet ve hem de işbirliği içinde bulunan, belirli alanlarda birbirine bağlı şirketler, uzman tedarikçiler, hizmet sağlayıcılar, ilgili sektörlerdeki firmalar ve bağlantılı kurumlardan (örneğin, üniversiteler, standart kurumları ve ticaret birlikleri) oluşan coğrafi yoğunlaşmalardır (Porter, 2011, s. 243). Şekil 1'de başlıca küme elemanları ve aralarındaki ilişkiler görülmektedir.

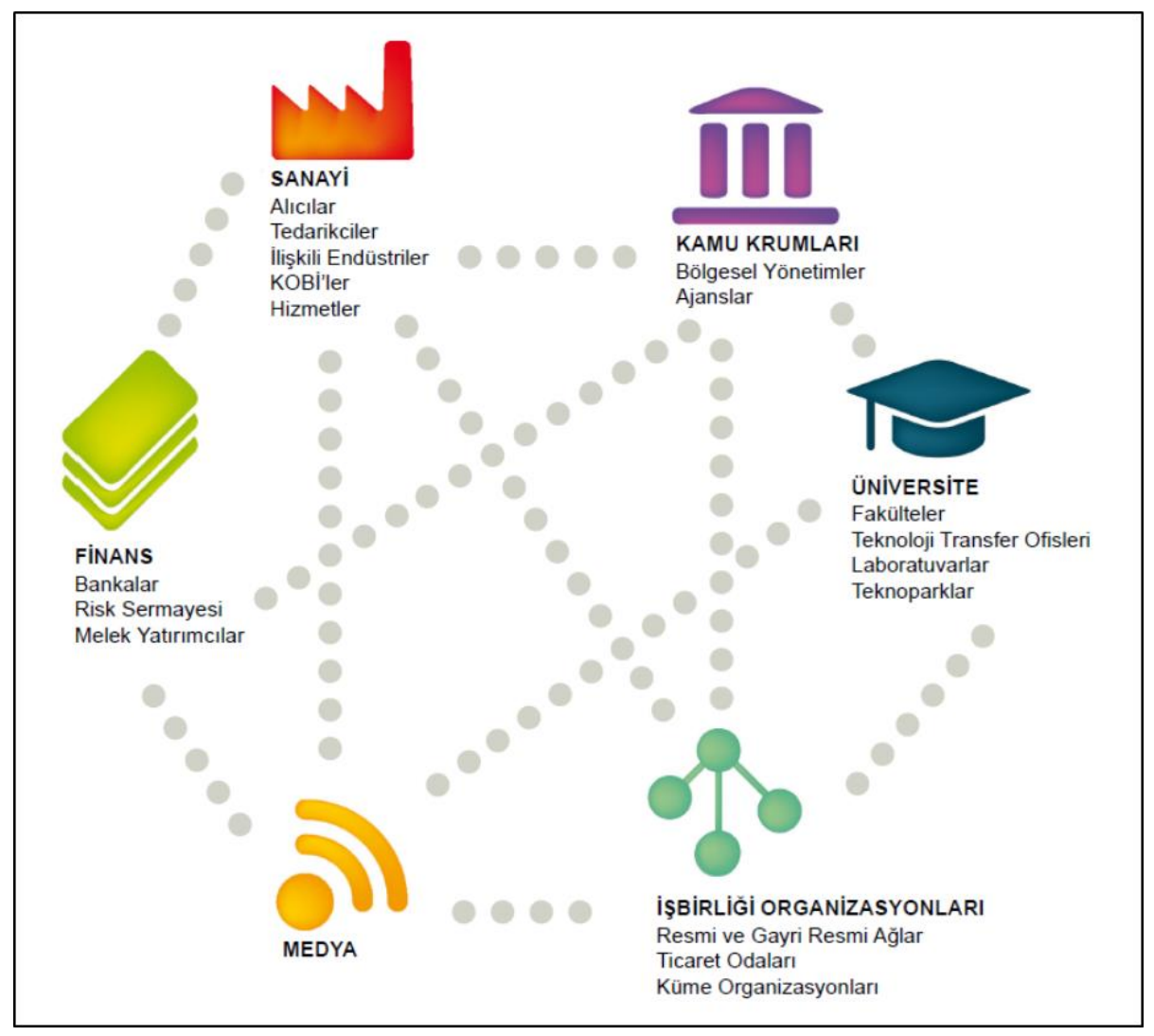

Şekil 1. Küme Elemanları

Kaynak: (Sölvell, 2009, s. 16)

Kümelenmenin işletmeler açısından sağladığı başlıca yararlar üretim faktörlerinin temininde maliyet avantajı kazandırması, işgücü ve ürün kalitesini, verimliliği, ihracatı ve satışları arttırması, teşvik almayı kolaylaştırması, Ar-Ge ve yenilik çalışmaları için destekler sunması olarak sayılabilir (Anokhin vd. 2019, s. 105). Bölge için sağladığı yararlar ise; bölgenin yatırımcılar için cazip hale gelmesi, yeni iş ve girişim sayısının artması, bölge ekonomisi ve rekabet gücünün gelişmesi, istihdamın artması olarak sıralanabilir. Ayrıca Üniversite-sanayi iş birliğini desteklenmesiyle Ar-Ge ve yenilik çalışmaları güçlenirken bilgi, yenilik ve teknolojiler hızla yayılır, eğitim ve danışmanlık faaliyetleri gelişmektedir (İAOSB, 2017), (Roberts \& Enright, 2004, s. 99-100). 
Çamlıca, Z., Şenkayas, H. / Journal of Yasar University, 2020, Special Issue on 3rd International EUREFE Congress, $88-105$

Kümeler genellikle doğal süreçte kendiliğinden oluşsalar da potansiyellerinin saptanarak gelişimlerinin desteklenmesi gerekmektedir. Bölge ekonomisine sağladıkları faydalar nedeniyle günümüzde kümelenmeler oluşumu devlet tarafından teşvik edilen bir bölgesel kalkınma aracı olarak karşımıza çıkmaktadır. Kümelenme Girişimleri, iş kümesinin gelişimini mevcut aktörler arasındaki ilişkileri düzenleyerek ve/veya iş birliği potansiyelini güçlendirerek arttırmayı hedefleyen organize çabaları ifade etmektedir (Ketels, Lindqvist, \& Sölvell, 2006, s. 9). Dünyanın farklı bölgelerinde pek çok başarılı kümelenme örneği bulunmaktadır. Kümelenme uygulamaları, özellikle 1990'lı yıllardan itibaren Batı, Orta ve Doğu Avrupa, Amerika Birleşik Devletleri, Çin Halk Cumhuriyeti ve Japonya dahil olmak üzere birçok ülkede başarıyla uygulanmış ve etkin sonuçlar alınmıştır (http://www.smenetworking.gov.tr, 2017).

Dünyadaki gelişmelere paralel olarak ülkemizde de 90'lı yılların sonlarından itibaren kümelenme ile ilgili çalışmaların başladığı görülmektedir. Kümelenmenin teşvik edilmesi son dönem kalkınma planları içinde yer almış, Organize Sanayi Bölgelerinin kümelenme yaklaşımıyla ele alınması gündeme gelmiş, OSTİM ve İAOSB gibi OSB'ler içinde başarılı kümelenmeler gerçekleştirilmiştir (Karataş, 2006), (Kök, Duygulu, \& Şimşek, 2010), (Erol \& Yıldırım, 2013), (Demir \& Dilek, 2016), (Şahin \& Özüdoğru 2019). Günümüze dek ulusal ve uluslararası pek çok farklı kurum ve kuruluşun işbirliği ile bir çok farklı proje ve faaliyet yürütülmüş ve desteklenmiş olmakla birlikte çalışmaların henüz yeterli düzeyde olmadığ söylenebilir.

\subsection{TR32 Bölgesinde Kümelenme Çalışmaları}

İstatistiki Bölge Birimleri Sınıflandırması uygulaması kapsamında Aydın (TR321), Denizli (TR322) ve Muğla (TR323) illerinden TR32 Düzey 2 Bölgesi oluşturulmuş ve Bölge ile ilgili faaliyetleri yürütmek üzere 2009 yılında Güney Ege Kalkınma Ajansı (GEKA) kurulmuştur. Tablo 1'de bölge illerine ait bazı temel göstergeler yer almaktadır.

Tablo 1. TR32 Bölgesine Ait Bazı Temel Göstergeler

\begin{tabular}{cccc}
\hline Gösterge & Aydın & Denizli & Muğla \\
\hline Yüzölçümü & $8.116 \mathrm{~km}^{2}$ & $11868 \mathrm{~km}^{2}$ & $12974 \mathrm{~km}^{2}$ \\
Nüfus (2017) & 1.080 .839 & 1.018 .735 & 938.751
\end{tabular}


Çamlıca, Z., Şenkayas, H. / Journal of Yasar University, 2020, Special Issue on 3rd International EUREFE Congress, $88-105$

Sosyo-ekonomik Gelişmişlik Endeksi (2013) 19. sıra 10. sıra $\quad$ 8. sıra

EDAM Rekabetçilik Endeksi (2016)

İhracat (\$) (2017)

İthalat $(\$)(2017)$

Orta-ileri Teknoloji Sektörlerin İhracat Payı

(2012)
18

$702.007 .432 \quad 2.677 .119 .184$

247.578 .889

2.009.358.381

275.578 .796

$\% 52$

$\% 13$

$\% 19$

Kaynak: (T.C.K.B., 2013), (EDAM, 2016), (URAK, 2016), (GEKA, 2018 a), (TÜIK, 2018)'den derlenmiştir.

GEKA, kuruluşundan itibaren bölgeyi kümelenme açısından değerlendiren çalışmaları da yürütmektedir. Bu kapsamda kurum tarafından 2011 yılında hazırlanan raporda Aydın için; “Gıda Ürünleri İmalatı” ve "Kömür ve Linyit Çıkartılması”, Denizli için; “Tekstil Ürünleri İmalatı", "Giyim Eşyaları İmalatı", "Fabrikasyon Metal Ürünleri İmalatı" ve "Kara Taşımacılığı ve Boru Hattı Taşımacılığı”, Muğla için; "Balıkçılık ve Su Ürünleri Yetiştiriciliği”, "Konaklama", "Diğer Madencilik ve Taş Ocakçılığı” ve "Bina İnşaatı" sektörleri kümelenme için uygun alanlar olarak belirlenmiştir (GEKA, 2011, s. 42-44).

T.C. Ekonomi Bakanlığı tarafından 2012 yılında hazırlanan Kümeler İçin Ortak Rekabet Alanları Stratejisi Raporu'nda ise bölge illeri için potansiyel kümeler şu şekilde sıralanmıştır (T.C.EB, 2012, s. 77-87); Aydın; Kuşadası Turizm Kümesi, Tarım Makinaları Üretim Kümesi, Gıda ve İçecek Ürünleri Kümesi, Çine Yatağan Feldspat Madenciliği Kümesi, Denizli; Enerji Kablosu Kümesi, Termal ve Sağlık Kümesi, Ev Tekstil Kümesi, Doğal Taş Kümesi, Yatağan Bıçakçılık Kümesi, Yeşilyuva Ayakkabıcılık Kümesi, Dericilik Kümesi, Serinhisar Kuruyemiş Kümesi, Muğla; Bodrum Yat İmalat Kümesi, Turizm Kümesi, Balıçc1lık Kümesi.

Günümüze kadar olan süreçte Kümelenmeyle ilgili GEKA tarafından Doğrudan Faaliyet Desteği kapsamında desteklenmiş iki proje bulunmaktadır. Bunlardan ilki; 2011 yılında Bodrum Ticaret Odası tarafından hazırlanan "Bodrum Yat İmalatı İş Kümesi Rotasını Çiziyor” isimli projedir (BODTO, 2012), (Bodrum Yat Kümesi, 2018), ikincisi ise; 2015 yılında MÜSİAD Denizli Şubesi tarafından hazırlanarak Denizli Ticaret Odası ortaklığı ile yürütülen “Kümelenmeye İlk Adım: Denizli Tekstil Sektörü Analizi” projesidir (MÜSİAD Denizli Şubesi, 2015), (DenizliTekstil.org, 2018). 
Çamlıca, Z., Şenkayas, H. / Journal of Yasar University, 2020, Special Issue on 3rd International EUREFE Congress, $88-105$

Literatürde TR32 Bölgesi ve bölge illerinde kümelenmeyi konu alan bilimsel araştırma ve yayınlar tarandığında ağırlıklı olarak Denizli ilinin ve tekstil sektörünün ele alındığı görülmektedir Öz (2003) ve (2004), Eraydın ve Fingleton (2006), Kuştepeli ve Gülcan (2010), Gülcan vd. (2011), Erenler vd. (2011), Çakmak (2012), Özpençe (2013), Aydemir ve Soydaş (2014). Erkut (2011) Aydın ilindeki potansiyel kümelenme alanlarını araştırırken, Muğla ili için yapılmış bir çalışmaya rastlanamamıştır. Yakın dönemde yapılmış, üç yıldız analizini kullanan iki farklı çalışmada ise TR32 Bölgesinin kümelenme potansiyeli tüm sektörler (İyem vd., 2018) ve imalat sektörleri (Akar, 2018) ele alınarak incelenmiştir.

\section{Analiz ve Bulgular}

Çalışmanın uygulama kısmında, eden imalat sektörleri esas alınarak ve bölgede yapılan önceki çalışmalardan farklı bir yaklaşım benimsenerek yapılan analizlerle TR32 Bölgesi illerindeki kümelenme potansiyeli değerlendirilmiştir. Kümelenme çalışmalarının planlanmasında sadece coğrafi yoğunluğu dikkate almak, yanlış seçim yapılmasına ve kümelenmenin bölgesel gelişime katkısının beklenenden düşük kalmasına sebep olabilir. $\mathrm{Bu}$ nedenle, bu bölümde yer alan analizler bölgede yoğunlaşmış sektörlerin belirlenmesinin yanında bu sektörler içinden rekabet gücü yüksek olanların saptanmasına olanak sağlayacak şekilde kurgulanmıştır.

\subsection{Metodoloji}

Çalışmada, SGK İstatistik Yıllıklarından (SGK, 2017) alınan İşyeri ve Sigortalı İstatistikleri’nden “Sigortalı Sayılarının Faaliyet Kolları ve İllere Göre Dağılımı” verilerinden yararlanılmış, TR32 Bölgesinde öne çıkan sektörlerin belirlenmesi Bölgesel Yoğunlaşma (Location Quotient - LQ), bölgesel yoğunlaşmanın fazla görüldüğü sektörler içerisinde rekabet gücü yüksek olabilecek sektörlerin belirlenmesi için ise Değişim Payı (Shift-Share) Analizi uygulanmıştır. Literatürde benzer yaklaşımı benimseyerek iki analizi bir arada kullanan çalışmalar mevcuttur (Kiser 1992), (Porter 2003), (Sambidi 2008), (Şenkayas, Çamlıca, \& Akar, 2016).

\subsubsection{Bölgesel Yoğunlaşma (Location Quotient-LQ) Analizi}

Belirli bir sanayinin yerelleşme düzeyinin belirlenmesinde en önemli tekniklerden olup genellikle istihdam verileri kullanılarak uygulanır. LQ belirli bir dönemdeki değişimlerle ilgili analitik bilgi üreterek bölge endüstrilerine yönelik stratejilerin geliştirilmesine katkı sağlar (Kumral, 2004, s. 67). LQ aşağıdaki gibi (1) formüle edilebilir (Isserman, 1977, s. 34) 
Çamlıca, Z., Şenkayas, H. / Journal of Yasar University, 2020, Special Issue on 3rd International EUREFE Congress, 88-105

\begin{tabular}{|l|l|}
$L Q=\frac{E_{i b} / E_{t b}}{E_{i u} / E_{t u}}$ & $\begin{array}{l}E_{i b:} \text { i sektörünün bölgedeki istihdamı } \\
E_{t b}: \text { bölgedeki toplam istihdam } \\
E_{\text {iu: }: \text { i sektörünün ülkedeki istihdamı }} \\
E_{t u}: \text { ülkedeki toplam istihdamı }\end{array}$ \\
\hline
\end{tabular}

LQ değerinin 1'e eşit veya 1'den büyük olması sektörün bölgesel yoğunluğunun ülkedeki yoğunluğuna eşit veya ülkeye göre daha yoğun gerçekleştiğini gösterirken (Morrissey, 2014, s. 60), katsayının büyüklügü oranında bölge için sürükleyici sektör olduğu yorumu yapılabilir (Bayraktutan, Tüylüoğlu, \& Özbilgin, 2012, s. 64). Bölgesel endüstriler LQ'nun belirli bir zaman dilimindeki değişimi kullanılarak Tablo 2'deki gibi dört kategoriye ayrılabilir;

Tablo 2. LQ’daki Değişimlere Göre Sektörlerin Değerlendirilmesi

\begin{tabular}{ccc} 
& Temel Yıl & Sonraki Dönem \\
\cline { 2 - 3 } Yıldızlar & $(\mathrm{LQ}>1)$ & Daha yüksek \\
Gelişenler & $(\mathrm{LQ}<1)$ & Daha yüksek \\
Olgunlar & $(\mathrm{LQ}>1)$ & Daha düşük \\
Dönüşenler & $(\mathrm{LQ}<1)$ & Daha düşük \\
\hline & & \\
\hline
\end{tabular}

\subsubsection{Değişim Payı (Shift Share) Analizi;}

Geleneksel olarak bölgesel kalkınmanın gelir, istihdam, katma değer gibi değişkenler kullanılarak değerlendirmesini amaçlar. Shift Share bir bölgenin sektörel büyümesini üç bileşene ayırarak açıklar (Brox \& Carvalho, 2008), Houston (1967). Belli bir endüstrinin, belli bir bölgede, belli bir zaman aralığında gerçekleşen büyümesi aşağıdaki (2), (3) ve (4) numaralı formüllerle hesaplanan edilen bu üç bileşenin toplamı ile ifade edilir (Jones, 2012, s. 1350), (Gardiner, Martin, Sunley, \& Tyler, 2013). 
Çamlıca, Z., Şenkayas, H. / Journal of Yasar University, 2020, Special Issue on 3rd International EUREFE Congress, 88-105

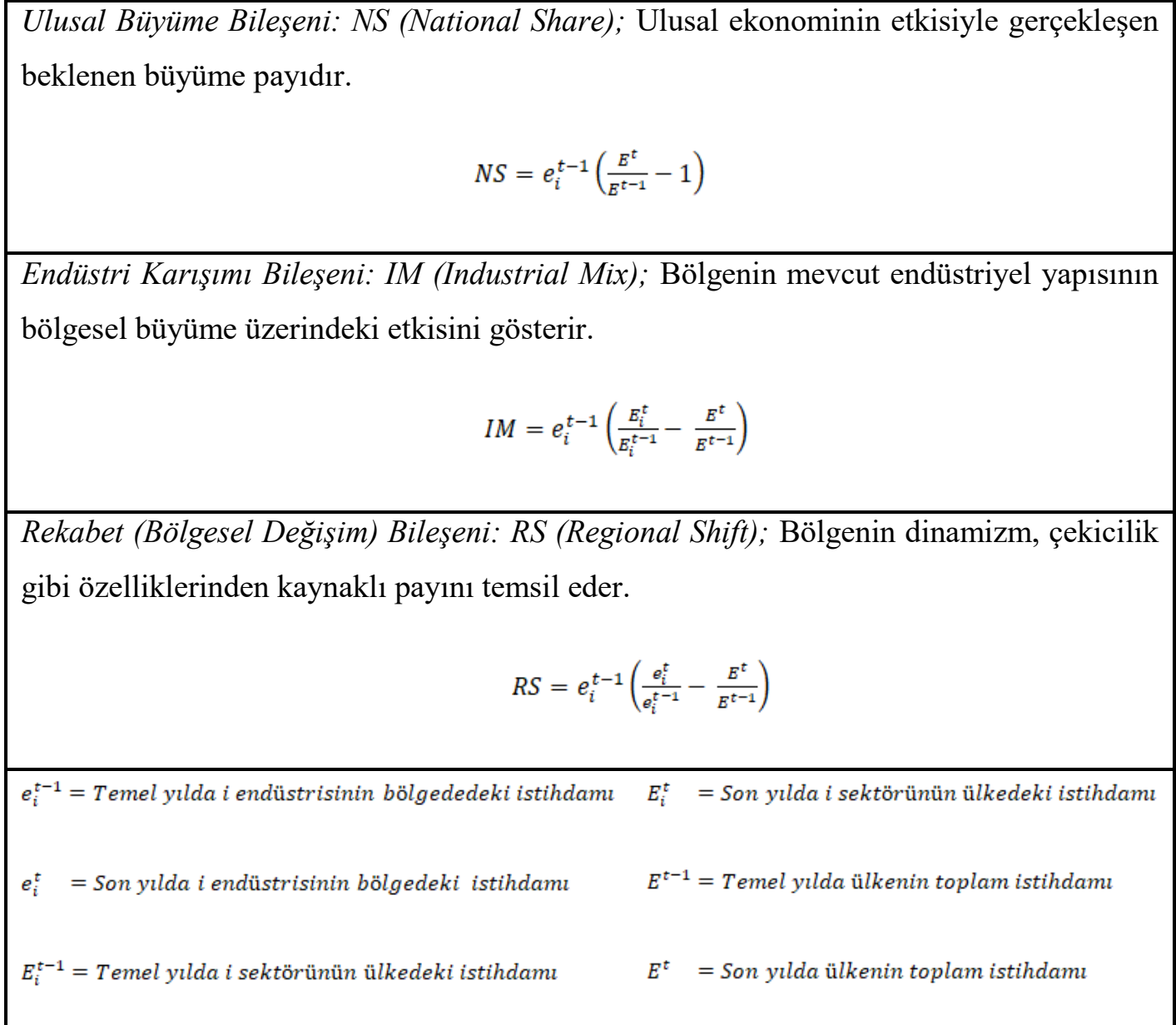

\subsection{Bulgular}

Bölge illerindeki imalat sektörlerinin 2010 ve 2015 y1llarına ait sektörel istihdam verileriyle hesaplanan yoğunlaşma katsayılarına göre sıralaması Tablo 3'te görülmektedir. Tablodak değerler, sektörlerin Tablo 2'ye göre konumlandırıldığı baloncuk grafikleri ile görselleştirilmiş ve izleyen bölümlerde, sektörlerin rekabet gücünü değerlendirmeye imkân veren değişim payı analizlerinin sonuçlarına ait grafiklerle birlikte, iller bazında sunulmuştur.

Tablo 3. TR32 Bölgesi İlleri İmalat sektörleri LQ sıralaması (2010-2015)

\begin{tabular}{c|cc|cc|cc}
\cline { 2 - 7 } \multicolumn{2}{c|}{ AYDIN } & \multicolumn{2}{c|}{ DENIZLI } & \multicolumn{2}{c}{ MUĞLA } \\
\hline \multirow{3}{*}{ Sira } & 2010 & 2015 & 2010 & 2015 & 2010 & 2015 \\
& $\begin{array}{c}\text { Nace Kodu } \\
(L Q)\end{array}$ & Nace Kodu & Nace Kodu & Nace Kodu & Nace Kodu & Nace Kodu \\
& $(L Q)$ & $(L Q)$ & $(L Q)$ & $(L Q)$ & $(L Q)$ \\
\hline \multirow{2}{*}{1} & 10 & 11 & 13 & 13 & 33 & 16 \\
& $(2,16)$ & $(3,08)$ & $(5,86)$ & $(6,41)$ & $(1,85)$ & $(1,66)$ \\
\hline \multirow{2}{*}{2} & 27 & 10 & 23 & 23 & 16 & 33 \\
& $(2,15)$ & $(2,39)$ & $(2,84)$ & $(3,03)$ & $(1,66)$ & $(1,37)$ \\
\hline
\end{tabular}


Çamlıca, Z., Şenkayas, H. / Journal of Yasar University, 2020, Special Issue on 3rd International EUREFE Congress, $88-105$

\begin{tabular}{|c|c|c|c|c|c|c|}
\hline 3 & $\begin{array}{c}16 \\
(1,73)\end{array}$ & $\begin{array}{c}28 \\
(2,34)\end{array}$ & $\begin{array}{c}14 \\
(1,85)\end{array}$ & $\begin{array}{c}17 \\
(1,53)\end{array}$ & $\begin{array}{c}23 \\
(1,35)\end{array}$ & $\begin{array}{c}23 \\
(1,37)\end{array}$ \\
\hline 4 & $\begin{array}{c}11 \\
(1,42)\end{array}$ & $\begin{array}{c}23 \\
(1,32) \\
\end{array}$ & $\begin{array}{c}11 \\
(1,82)\end{array}$ & $\begin{array}{c}14 \\
(1,45) \\
\end{array}$ & $\begin{array}{c}30 \\
(1,31) \\
\end{array}$ & $\begin{array}{c}10 \\
(0,83) \\
\end{array}$ \\
\hline 5 & $\begin{array}{c}23 \\
(1,34)\end{array}$ & $\begin{array}{c}16 \\
(1,19)\end{array}$ & $\begin{array}{c}17 \\
(1,42)\end{array}$ & $\begin{array}{c}16 \\
(1,16)\end{array}$ & $\begin{array}{c}10 \\
(0,67)\end{array}$ & $\begin{array}{c}30 \\
(0,83)\end{array}$ \\
\hline 6 & $\begin{array}{c}33 \\
(0,99) \\
\end{array}$ & $\begin{array}{c}25 \\
(0,66) \\
\end{array}$ & $\begin{array}{c}16 \\
(1,27)\end{array}$ & $\begin{array}{c}19 \\
(1,09)\end{array}$ & $\begin{array}{c}26 \\
(0,62)\end{array}$ & $\begin{array}{c}11 \\
(0,72)\end{array}$ \\
\hline 7 & $\begin{array}{c}20 \\
(0,91)\end{array}$ & $\begin{array}{c}29 \\
(0,60)\end{array}$ & $\begin{array}{c}25 \\
(1,06)\end{array}$ & $\begin{array}{c}24 \\
(0,93)\end{array}$ & $\begin{array}{c}11 \\
(0,57)\end{array}$ & $\begin{array}{c}26 \\
(0,33)\end{array}$ \\
\hline 8 & $\begin{array}{c}30 \\
(0,83) \\
\end{array}$ & $\begin{array}{c}30 \\
(0,58) \\
\end{array}$ & $\begin{array}{c}33 \\
(0,90) \\
\end{array}$ & $\begin{array}{c}25 \\
(0,91) \\
\end{array}$ & $\begin{array}{c}32 \\
(0,36) \\
\end{array}$ & $\begin{array}{c}25 \\
(0,33) \\
\end{array}$ \\
\hline 9 & $\begin{array}{c}26 \\
(0,65)\end{array}$ & $\begin{array}{c}27 \\
(0,53)\end{array}$ & $\begin{array}{c}31 \\
(0,69)\end{array}$ & $\begin{array}{c}11 \\
(0,89)\end{array}$ & $\begin{array}{c}31 \\
(0,32)\end{array}$ & $\begin{array}{c}31 \\
(0,32)\end{array}$ \\
\hline 10 & $\begin{array}{c}13 \\
(0,62)\end{array}$ & $\begin{array}{c}20 \\
(0,52) \\
\end{array}$ & $\begin{array}{c}18 \\
(0,57) \\
\end{array}$ & $\begin{array}{c}18 \\
(0,76) \\
\end{array}$ & $\begin{array}{c}20 \\
(0,32) \\
\end{array}$ & $\begin{array}{c}18 \\
(0,27) \\
\end{array}$ \\
\hline 11 & $\begin{array}{c}25 \\
(0,59) \\
\end{array}$ & $\begin{array}{c}31 \\
(0,50)\end{array}$ & $\begin{array}{c}10 \\
(0,54)\end{array}$ & $\begin{array}{c}33 \\
(0,70)\end{array}$ & $\begin{array}{c}25 \\
(0,30)\end{array}$ & $\begin{array}{c}17 \\
(0,25)\end{array}$ \\
\hline 12 & $\begin{array}{c}28 \\
(0,52)\end{array}$ & $\begin{array}{c}26 \\
(0,49)\end{array}$ & $\begin{array}{c}22 \\
(0,52)\end{array}$ & $\begin{array}{c}10 \\
(0,69)\end{array}$ & $\begin{array}{c}18 \\
(0,28)\end{array}$ & $\begin{array}{c}32 \\
(0,21)\end{array}$ \\
\hline 13 & $\begin{array}{c}24 \\
(0,48)\end{array}$ & $\begin{array}{c}13 \\
(0,47) \\
\end{array}$ & $\begin{array}{c}27 \\
(0,51) \\
\end{array}$ & $\begin{array}{c}22 \\
(0,60) \\
\end{array}$ & $\begin{array}{c}17 \\
(0,27) \\
\end{array}$ & $\begin{array}{c}20 \\
(0,15) \\
\end{array}$ \\
\hline 14 & $\begin{array}{c}14 \\
(0,39)\end{array}$ & $\begin{array}{c}33 \\
(0,46) \\
\end{array}$ & $\begin{array}{c}19 \\
(0,44)\end{array}$ & $\begin{array}{c}20 \\
(0,60)\end{array}$ & $\begin{array}{c}22 \\
(0,11)\end{array}$ & $\begin{array}{c}22 \\
(0,10) \\
\end{array}$ \\
\hline 15 & $\begin{array}{c}29 \\
(0,36)\end{array}$ & $\begin{array}{c}22 \\
(0,31)\end{array}$ & $\begin{array}{c}24 \\
(0,39)\end{array}$ & $\begin{array}{c}32 \\
(0,59)\end{array}$ & $\begin{array}{c}28 \\
(0,09)\end{array}$ & $\begin{array}{c}24 \\
(0,08)\end{array}$ \\
\hline 16 & $\begin{array}{c}22 \\
(0,34) \\
\end{array}$ & $\begin{array}{c}19 \\
(0,31) \\
\end{array}$ & $\begin{array}{c}26 \\
(0,39) \\
\end{array}$ & $\begin{array}{c}31 \\
(0,58) \\
\end{array}$ & $\begin{array}{c}14 \\
(0,06)\end{array}$ & $\begin{array}{c}13 \\
(0,08) \\
\end{array}$ \\
\hline 17 & $\begin{array}{c}31 \\
(0,34)\end{array}$ & $\begin{array}{c}14 \\
(0,26)\end{array}$ & $\begin{array}{c}32 \\
(0,37)\end{array}$ & $\begin{array}{c}27 \\
(0,57)\end{array}$ & $\begin{array}{c}27 \\
(0,05)\end{array}$ & $\begin{array}{c}28 \\
(0,05)\end{array}$ \\
\hline 18 & $\begin{array}{c}32 \\
(0,30)\end{array}$ & $\begin{array}{c}24 \\
(0,25)\end{array}$ & $\begin{array}{c}15 \\
(0,35)\end{array}$ & $\begin{array}{c}15 \\
(0,36)\end{array}$ & $\begin{array}{c}13 \\
(0,05)\end{array}$ & $\begin{array}{c}27 \\
(0,04)\end{array}$ \\
\hline 19 & $\begin{array}{c}18 \\
(0,27)\end{array}$ & $\begin{array}{c}17 \\
(0,25)\end{array}$ & $\begin{array}{c}20 \\
(0,28)\end{array}$ & $\begin{array}{c}28 \\
(0,35)\end{array}$ & $\begin{array}{c}24 \\
(0,05)\end{array}$ & $\begin{array}{c}15 \\
(0,03)\end{array}$ \\
\hline 20 & $\begin{array}{c}17 \\
(0,24) \\
\end{array}$ & $\begin{array}{c}18 \\
(0,24) \\
\end{array}$ & $\begin{array}{c}28 \\
(0,12) \\
\end{array}$ & $\begin{array}{c}26 \\
(0,24)\end{array}$ & $\begin{array}{c}15 \\
(0,03)\end{array}$ & $\begin{array}{c}29 \\
(0,02)\end{array}$ \\
\hline 21 & $\begin{array}{c}19 \\
(0,12)\end{array}$ & $\begin{array}{c}32 \\
(0,13)\end{array}$ & $\begin{array}{c}30 \\
(0,05)\end{array}$ & $\begin{array}{c}30 \\
(0,06)\end{array}$ & $\begin{array}{c}29 \\
(0,02)\end{array}$ & $\begin{array}{c}14 \\
(0,02)\end{array}$ \\
\hline 22 & $\begin{array}{c}15 \\
(0,06)\end{array}$ & $\begin{array}{c}15 \\
(0,05) \\
\end{array}$ & $\begin{array}{c}29 \\
(0,02) \\
\end{array}$ & $\begin{array}{c}21 \\
(0,05) \\
\end{array}$ & $\begin{array}{c}19 \\
(0,01)\end{array}$ & $\begin{array}{c}19 \\
(0,01)\end{array}$ \\
\hline 23 & $\begin{array}{c}12 \\
(0,00)\end{array}$ & $\begin{array}{c}12 \\
(0,00) \\
\end{array}$ & $\begin{array}{c}21 \\
(0,02)\end{array}$ & $\begin{array}{c}29 \\
(0,02) \\
\end{array}$ & $\begin{array}{c}21 \\
(0,01)\end{array}$ & $\begin{array}{c}12 \\
(0,00) \\
\end{array}$ \\
\hline 24 & $\begin{array}{c}21 \\
(0,00) \\
\end{array}$ & $\begin{array}{c}21 \\
(0,00)\end{array}$ & $\begin{array}{c}12 \\
(0,00) \\
\end{array}$ & $\begin{array}{c}12 \\
(0,00) \\
\end{array}$ & $\begin{array}{c}12 \\
(0,00)\end{array}$ & $\begin{array}{c}21 \\
(0,00) \\
\end{array}$ \\
\hline
\end{tabular}




\subsubsection{Aydın}

Şekil 2 ve 3'teki grafiklere göre; Aydın ilinde, Gıda ve İçecek İmalatı sektörlerinin yıldız, Makine ve Ekipman İmalatı sektörü gelişen sektör olarak görünürken rekabetçilik açısından Makine ve Ekipman ile Gıda Ürünleri İmalatı sektörleri ağırlıkta olmak üzere, Motorlu Kara Taşıtı ve Römork, Fabrikasyon Metal Ürünler (Makine Teçhizat Hariç) ve Mobilya İmalatı güçlü sektörler olarak sıralanmaktadır.

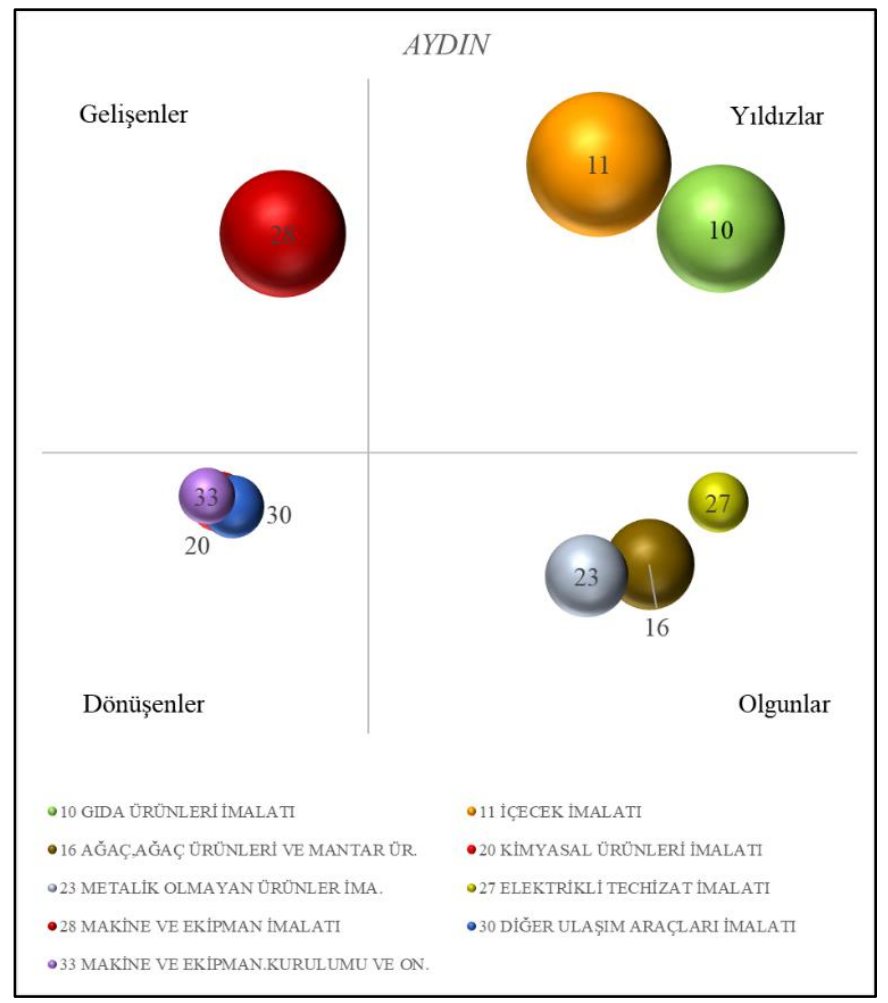

Şekil 2. Aydın İlinde İmalat Sektörlerinin Durumu 


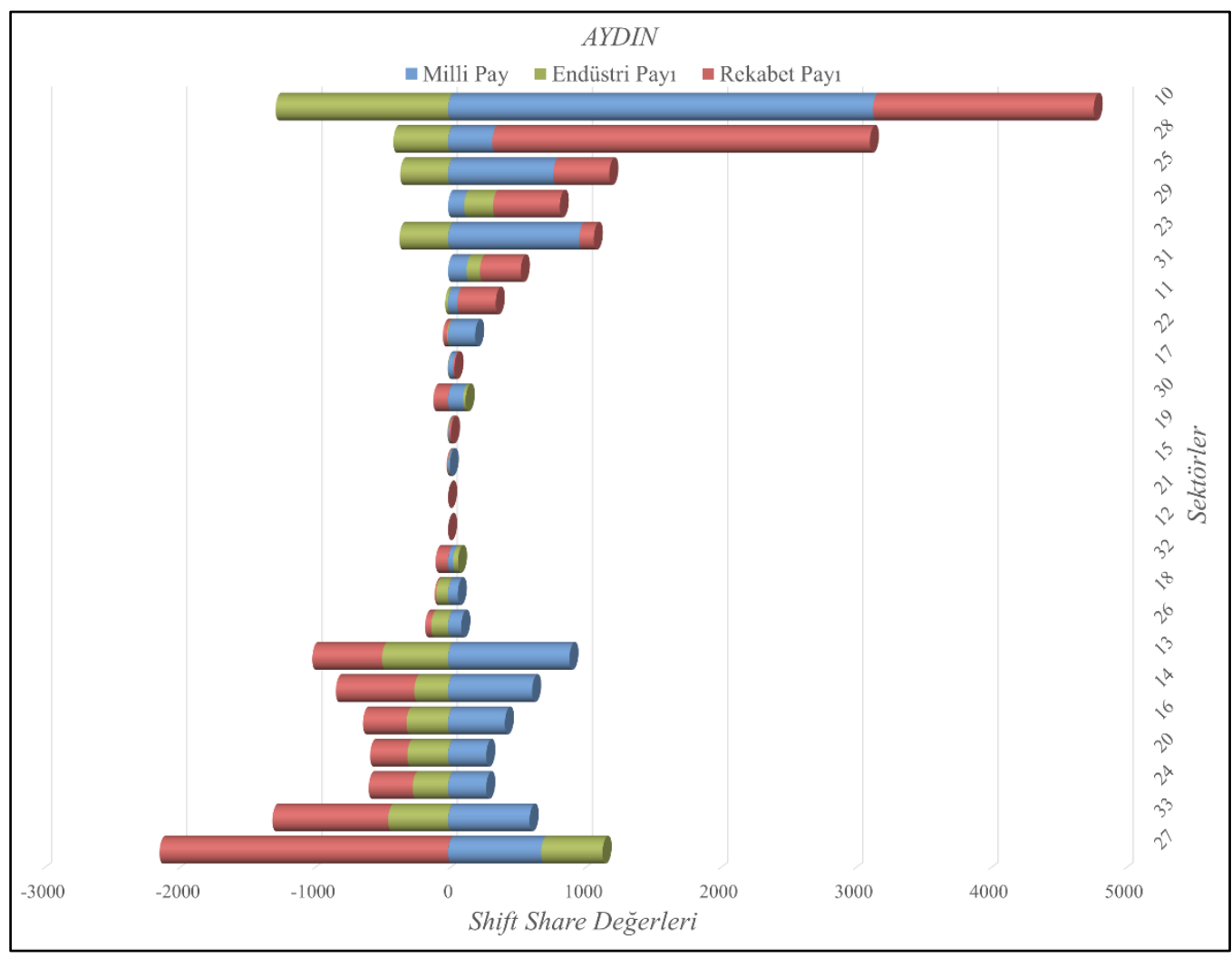

Şekil 3. Aydın İli İmalat Sektörlerinde Shift Share Paylarının Dağılımı

\subsubsection{Denizli}

Şekil 4 ve 5'te yer alan grafiklere göre; Denizli ilinde, Tekstil, Metalik Olmayan Ürünler, Kâğıt ve Kâğıt Ürünleri İmalatı sektörlerinin yıldız, Kayıtlı Medyanın Basılması ve Çoğaltılması, Kok Kömürü ve Petrol Ürünleri İmalatı ve Ana Metal Sanayi sektörleri gelişen sektörlerdir. Rekabetçilikte ise sırasıyla Tekstil Ürünleri, Ana Metal Sanayi, Gıda Ürünleri, Makine ve Ekipman ile Kimyasal Ürünler imalatı sektörleri önde görünmektedir. 
Çamlıca, Z., Şenkayas, H. / Journal of Yasar University, 2020, Special Issue on 3rd International EUREFE Congress, $88-105$

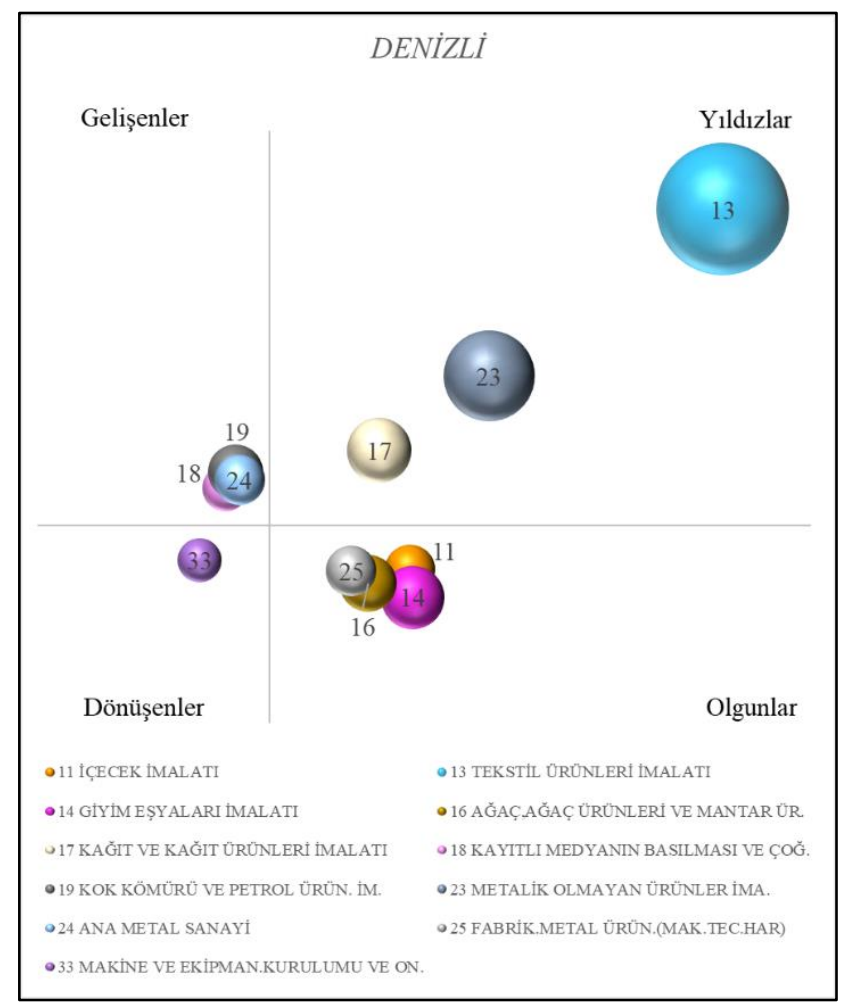

Şekil 4. Denizli İlinde İmalat Sektörlerinin Durumu

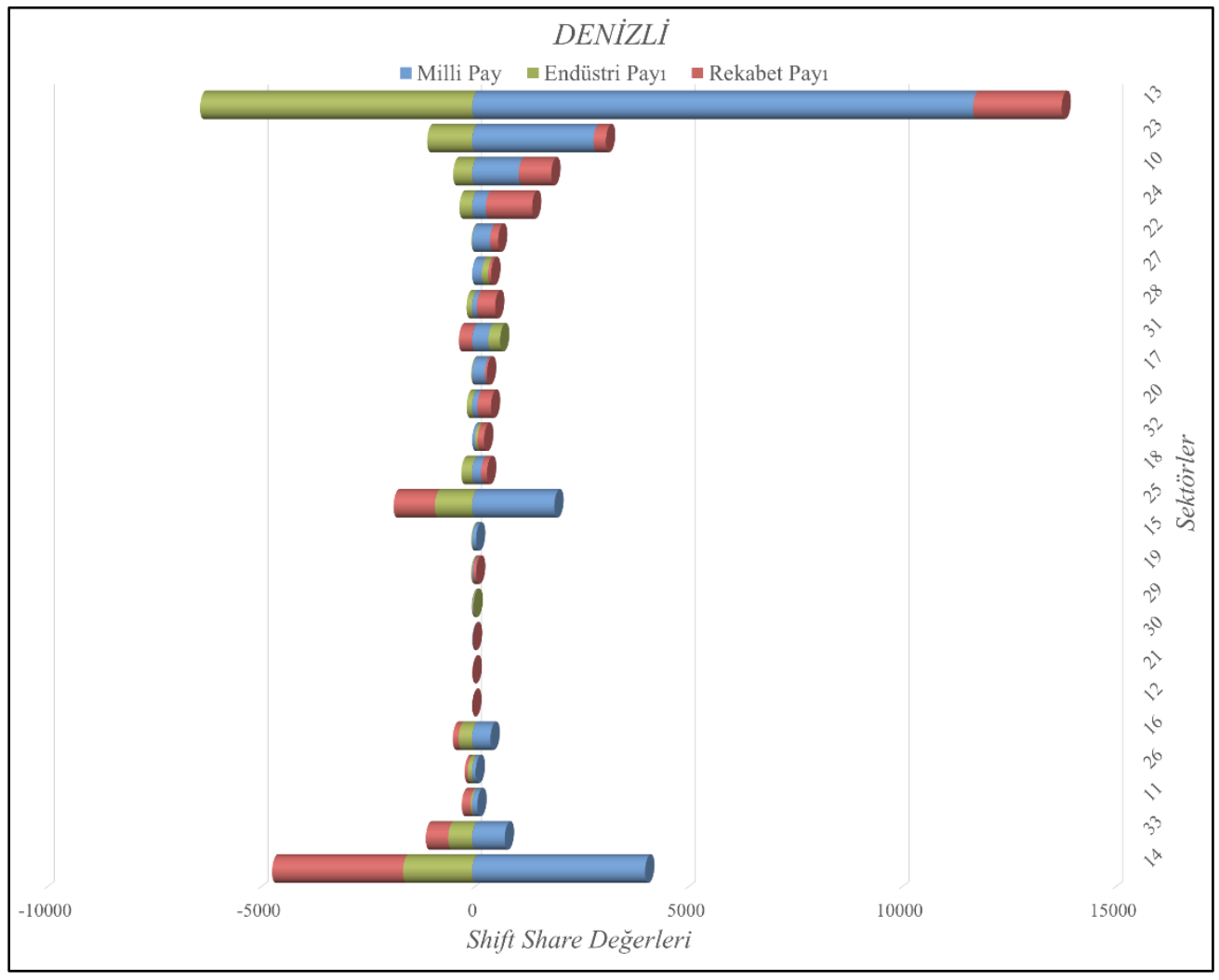

Şekil 5. Denizli İli İmalat Sektörlerinde Shift Share Paylarının Dağılımı 


\subsubsection{Muğla}

Şekil 6 ve 7'deki grafikler incelendiğinde; Muğla ilinde, Metalik Olmayan Ürünler imalatı sektörü yıldız, Gıda ve İçecek İmalatı sektörleri yükselen sektörlerdir. Rekabet gücü açısından sektörler başta Gıda Ürünleri İmalatı olmak üzere Metalik Olmayan Ürünler, Fabrikasyon Metal Ürünler (Makine Teçhizat Hariç), Tekstil Ürünleri İmalatı ve Ana Metal Sanayi olarak siralanmaktadir.

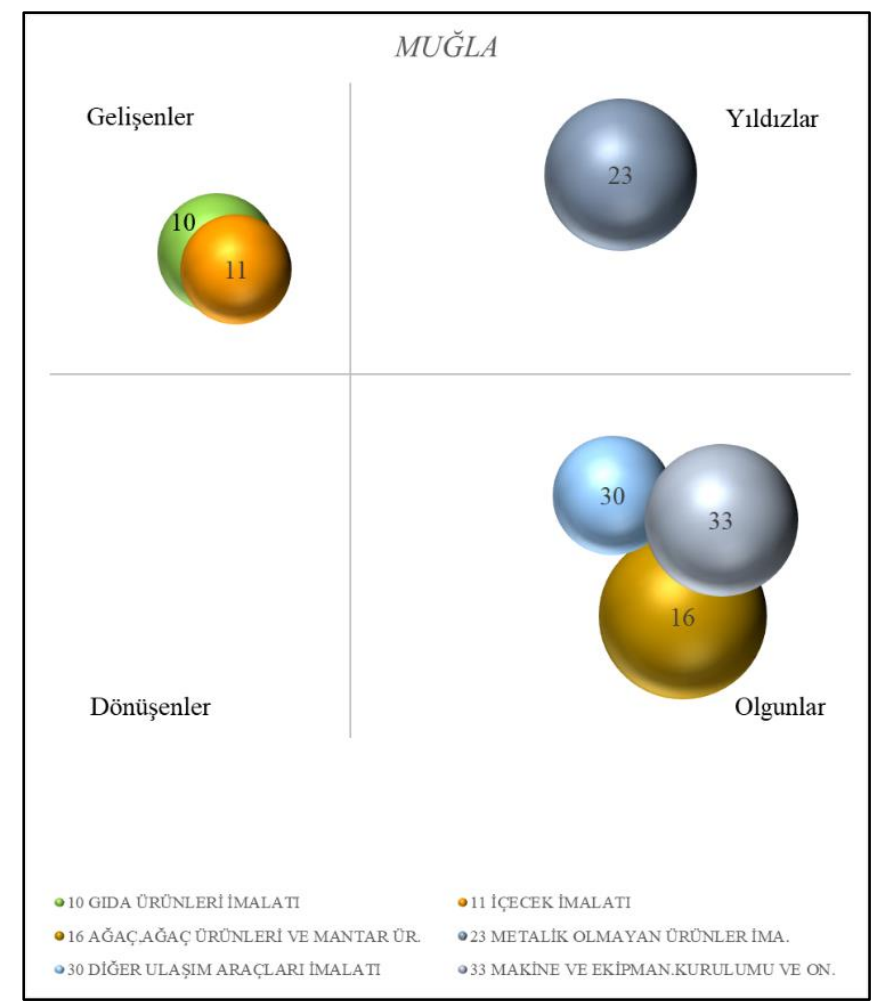

Şekil 6. Muğla İlinde İmalat Sektörlerinin Durumu 


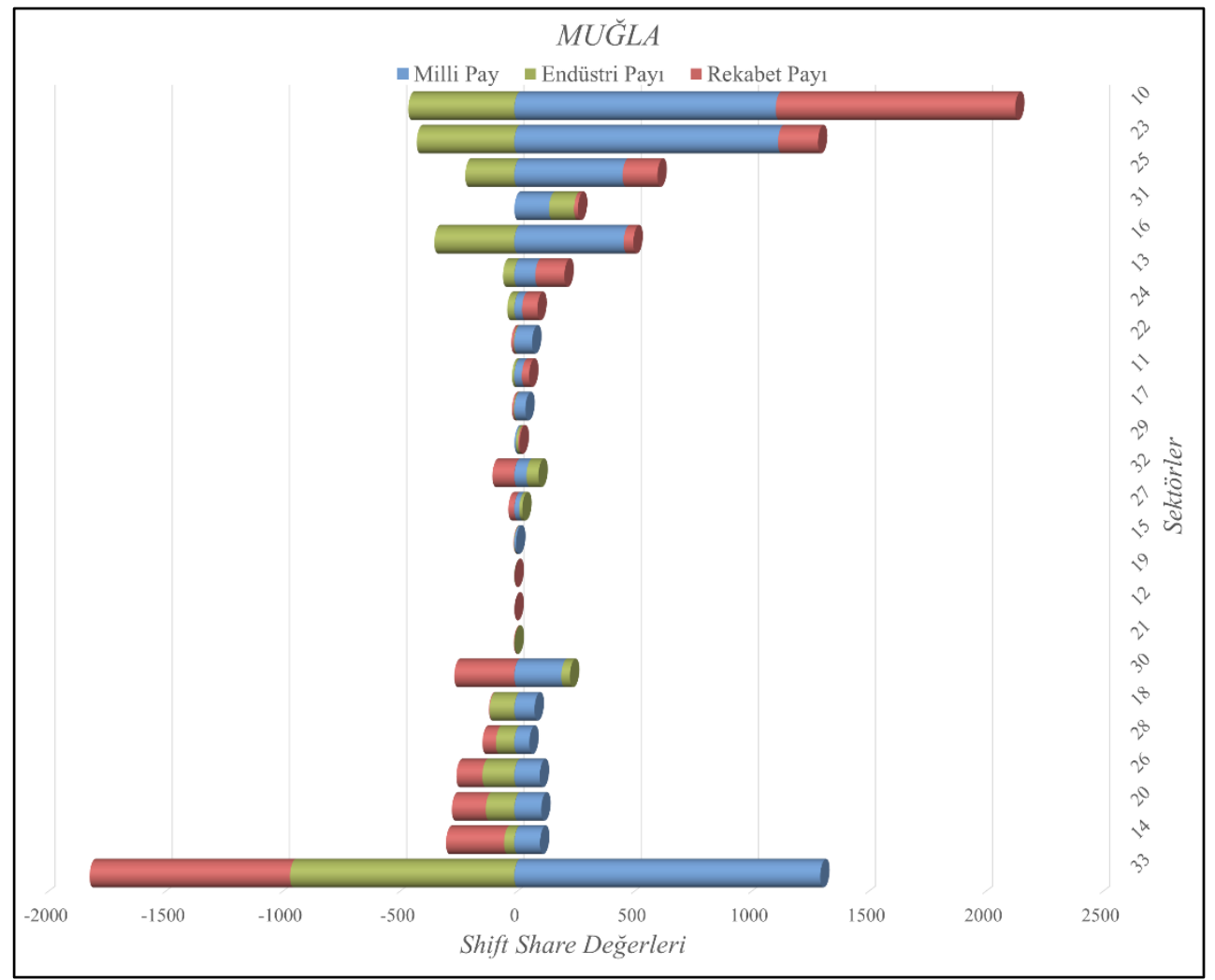

Şekil 7. Muğla İli İmalat Sektörlerinde Shift Share Paylarının Dağılımı

\section{Sonuç}

Bölgede Kümelenme ile ilgili faaliyetlerin oldukça yetersiz kaldığı görülmektedir. Denizli ve Muğla illerinde gerçekleştirilmiş bazı faaliyetler bulunmakla birlikte Aydın ilinde henüz başlatılmış herhangi bir girişim bulunmamaktadır. Bölge illerinde ilgili tarafların katılımı ve işbirliği ile kümelenme faaliyetlerinin en kısa zamanda başlatılması bölgenin kalkınması, ekonomik ve endüstriyel büyümesi için elzemdir.

Çalışmanın bulguları kümelenme çalışmalarının başlatılması için uygun olabilecek sektörleri işaret etmektedir. Bu bulgular doğrultusunda: Aydın ili için; Makine ve Ekipman İmalatı ve Gıda Ürünleri İmalatı, Denizli ili için; Tekstil Ürünleri İmalatı ve Ana Metal Sanayi, Muğla ili için: Gıda Ürünleri İmalatı ve Metalik Olmayan Ürünler İmalatı sektörleri kümelenme çalışmaları için öncelikli olarak önerilebilecek faaliyet kollarıdır.

Yoğunluk ve rekabetçilik önemli göstergeler olmakla birlikte kümelenme çalışmalarının yürütüleceği sektörlerin belirlenmesinde bölgesel, sektörel ve yerel dinamiklerin de dikkate alınması istenen amaçlara ulaşmada etkili olacaktır. Karar sürecinde firma sayıları ve büyüklükleri, ilgili meslek kuruluşlarının varlığı ve etkinliği, üniversite ile işbirliği olanakları, 
yerel kaynaklardan faydalanma düzeyi, sektörün teknolojik boyutu gibi parametrelerin değerlendirilmesi ile daha sağlıklı sonuçlara ulaşılabilecektir.

Coğrafi yakınlık bağlamında sektörler ve firmalar düzeyinde mevcut ve potansiyel işbirliklerinin araştırılması ve desteklenmesi kümelerin başlatılması ve geliştirilmesi için bir itici güç unsuru olarak değerlendirilebilir. Üniversiteler ile diğer eğitim ve araştırma kuruluşlarının sürece dahil edilmesi mutlaka sağlanmalı, tüm paydaşlar arasında işbirliği ve bilgi değişimine dayalı ağlarının gelişimi teşvik edilmelidir. 
Çamlıca, Z., Şenkayas, H. / Journal of Yasar University, 2020, Special Issue on 3rd International EUREFE

Congress, 88-105

\section{KAYNAKÇA}

Akar, D. (2018). Güney Ege İmalat Sektöründe Kümelenme Analizi. Güney Ege, 5(18), 4-7.

Anokhin, S., Wincent, J., Parida, V., Chistyakova, N. ve Oghazi, P. (2019). "Industrial clusters, flagship enterprises and regional innovation", Entrepreneurship \& Regional Development, 31(1-2), 104-118.

Arslan, K. (2005). "Bölgesel Kalkınma Farklılıklarının Giderilmesinde Etkin Bir Araç: Bölgesel Planlama ve Bölgesel Kalkınma Ajansları". İstanbul Ticaret Üniversitesi Sosyal Bilimler Dergisi, 4(7), 275-294.

Aydemir , B., ve Soydaş, M. (2014). Denizli İli Turizm Kümelenme Potansiyeli. Pamukkale Journal of Eurasian Socioeconomic Studies, 1(2), 13-26.

Bayraktutan, Y., Tüylüoğlu, Y.ve Özbilgin, M. (2012)." Lojistik Sektöründe Yoğunlaşma Analizi ve Lojistik Gelişmişlik Endeksi: Kocaeli Örneği". Uluslararası Alanya İşletme Fakültesi Dergisi, 4(3), 61-71.

Bodrum Yat Kümesi. (2018), http://bodrumyatkumesi.org (02.02.2018).

BODTO. (2012). "Bodrum Yat İmalatı İş Kümesi Rotasını Çiziyor Bodrum Yat İmalat Sektörü Envanter Raporu". Muğla: Bodrum Ticaret Odası.

Brox, J.ve Carvalho, E. (2008). "A Demographically Augmented Shift-Share Employment Analysis: An Application to Canadian Employment Patterns", The Journal of Regional Analysis and Policy, 38(2), 5666.

Çakmak , G. (2012). The Interplay Of The Global And The Local: The Socio-Economıc Development Of The Towel And Bathrobe Cluster Of Denizli. Boğaziçi Üniversitesi Atatürk İlkeleri ve İnkılâp Tarihi Enstitüsü Modern Türk Tarihi Yüksek Lisans Programı Yüksek Lisans Tezi. İstanbul.

Demir, S.ve Dilek, A. (2016). "İzmir Endüstriyel Havalandırma İklimlendirme Soğutma (Ehis) Kümesinin Normatif Açıdan Analizi". Journal of Current Researches on Business and Economics, 6(1), 79-92.

DenizliTekstil.org. (2018), https://www.denizlitekstil.org/ (02.02.2018).

EDAM. (2016). "Türkiye İçin Bir Rekabet Endeksi", İstanbul: Ekonomi ve Dış Politika Araştırmalar Merkezi .

Eraydın, A., ve Fingleton, B. (2006). Network Relations and Local Economic Development: Some Causes of Differentiated Network Structures and İntensities Among Turkish İndustrial Firms. Environment and Planning A, 38, 1171-1186.

Erenler , G., Alüftekin , N., Yüksel , Ö., Taş, A., ve Bayraktar, F. (2011). Denizli Tekstil Hazırgiyim Sektörü Bölgesel Yoğunlaşma (Kümelenme) Göstergeleri. Endüstri Mühendisliği Dergisi, 23(2), 2-27.

Erkut, F. (2011). Kümelenme ve Aydın İlindeki Kümelenme Potansiyeli Olan Alanlar. Yayımlanmamış Doktora Tezi, Adnan Menderes Üniversitesi Sosyal Bilimler Enstitüsü. Aydın.

Erol, D.ve Yıldırım, K. (2013). "Türkiye'de Kümelenme Yaşam Döngüsü: OSTİM Medikal Sanayi Kümelenmesi Örneği". Verimlilik Dergisi, 2013(2), 39-62.

Gardiner, B., Martin, R., Sunley, P.ve Tyler, P. (2013). "Spatially unbalanced growth in the British economy". Journal of Economic Geography, 13, 889-928.

GEKA. (2011). "TR32 Düzey II Bölgesi’nde Kümelenme Yaklaşımı". Denizli: Güney Ege Kalkınma Ajansı.

GEKA. (2018). TR 32 Bölgesi (Aydın-Denizli-Muğla) Sosyo-Ekonomik Göstergeleri. Denizli: T.C. Güney Ege Kalkınma Ajans1.

Gülcan, Y., Akgüngör, S., ve Kuştepeli, Y. (2011). Knowledge Generation and Innovativeness in Turkish Textile Industry: Comparison of Istanbul and Denizli. European Planning Studies, 19(7), 1229-1243.

İAOSB. (2017). "Kümelenme http://www.iaosb.org.tr: http://www.iaosb.org.tr/icerik/kumelenme/kumelenme-nedir (30.11.2017)

Isserman, A. (1977). "The Location Quotient Approach the Estimating Regional Economic Impacts". Journal of the American Institute of Planners, 43(1), 33-41.

İyem, C., Öztürk, D., ve Yıldız, F. (2018). Clustering and Clustering Potential in TR 32 Regions Province. International Journal of Academic Research in Accounting, Finance and Management Sciences, 8(3), 336-345.

Jones, P. S. (2012). "Job Creation and Regional Change Under New Labour: A Shift-Share Analysis. Environment and Planning", 44, 1348-1362.

Karataş, N. (2006). "Firma Kümeleşme Eğilimleri Üzerine Ampirik Bir Araştırma": İzmir

Ketels, C., Lindqvist, G.ve Sölvell, Ö. (2006). "Cluster Initiatives in Developing and Transition Economies". Stockholm: Center for Strategy and Competitiveness.

Kiser, D. (1992). "A Location Quotient and Shift Share Analysis of Regional Economies in Texas" . Southwest Texas State Unvversity The Department of Political Science Masters of Public Administration. Texas: Southwest Texas State University.

KOBİ İşbirliği ve Kümelenme Projesi (2017), http://www.smenetworking.gov.tr. (2017, 12 6).

Kök, R., Duygulu, E.ve Şimşek, N. (2010). "Turkıye'de Organize Sanayi Bölgelerinin Performans Değerlendirmesi ve Strateji Geliştirme (Alt Bölgeler Arası Karşılaştırma)". İzmir: Dokuz Eylül Üniversitesi.

Kumral, N. (2004)." Endüstriyel Yerelleşme: Türkiye NUTS 1 Bölgeleri Örneği". İktisat İşletme ve Finans, $19(215), 66-75$. 
Kuştepeli, Y., ve Gülcan, Y. (2010). Türk Tekstil Kümelerindeki Bilgi Tabanı Farklılıklarının Ölçümü ve Yenilikçilik. Gazi Üniversitesi İktisadi ve İdari Bilimler Fakültesi Dergisi, 12(1), 57-76.

Öz, Ö. (2003). Changing Patterns Of Competitive Advantage: The Towel/Bathrobe Cluster in Denizli (Turkey). Clusters, Industrial Districts and Firms: The Challenge of Globalisation Conference (12-13 Eylül 2003Modena-İtaly). Modena.

Öz, Ö. (2004). Clusters and Competitive Advantage: The Turkish Experience . New York: Palgrave Macmillan.

Özpençe,, A. İ. (2013). Kümelenmenin Pozitif Dışsallıklara Etkisi: Denizli Örneği. Pamukkale Üniversitesi Sosyal Bilimler Enstitüsü Maliye Anabilim Dalı Doktora Tezi. Denizli.

Morrissey, K. (2014). "Producing regional production multipliers for Irish marine sector policy: A location quotient approach". Ocean \& Coastal Management(91), 58e64.

MÜSİAD Denizli Şubesi. (2015). "Denizli Ev Tekstil Sektörü Analiz Raporu". Denizli: MÜSİAD Denizli Şubesi.

Porter, M. (2003). "The Economic Performance of Regions". Regional Studies, 37(6-7), 549-578.

Porter, M. (2011). "Rekabet Üzerine". (K. Tanrıar, Çev.) İstanbul: Türkiye İhracatçlar Meclisi.

Roberts, B.ve Enright, M. (2004). "İndustry Cluster in Australia: Recent Trends and Prospect", European Planning Studies, 12(1), 99-121.

Sambidi, P. (2008). "Regional Industry Cluster Analysis for the Gulf Coast Economic Development District". Houston: Gulf Coast Economic Development District Houston-Galveston Area Council.

SGK. (2017, 08 15)." SGK İstatistik Yıllıkları". T.C. Sosyal Güvenlik Kurumu: http://www.sgk.gov.tr/wps/portal/sgk/tr/kurumsal/istatistik/sgk_istatistik_yilliklari adresinden alındı

Sölvell, Ö. (2009). "Clusters: Balancing Evolutionary and Constructive Forces". Stockholm: Ivory Tower Publisher.

Şahin, B. D., Özüdoğru, H. (2019). "KOBI’lerde Üretim ve Pazarlama Sorunları: Ostim Örneği", Üçüncü Sektör Sosyal Ekonomi Dergisi, 54(1), 320 - 333.

Şenkayas, H., Çamlıca, Z.ve Akar, G. (2016). "TR32 Bölgesinde Endüstri 4.0 İçin Uygun Olabilecek Sektörlerin Araştırılması". Uluslararası Katılımlı 16. Üretim Araştırmaları Sempozyumu (12-14 Ekim 2016) Bildiri Kitabı (s. 1017-1022). İstanbul : İstanbul Teknik Üniversitesi İşletme Fakültesi İşletme Mühendisliği Bölümü.

T.C.E.B. (2012). "Kümeler İçin Ortak Rekabet Alanları Stratejisi Raporu-KOBİ İşbirliği ve Kümelenme Projesi". Ankara: T.C. Ekonomi Bakanlığı İhracat Genel Müdürlüğü. 12 18, 2017 tarihinde http://www.smenetworking.gov.tr/userfiles/pdf/KOBI-İşbirliğiveKümelenmeProjesiOrtakRekabetAlanları\%20Strateji\%20Raporu.pdf adresinden alındı

T.C.K.B. (2013). "İllerin ve Bölgelerin Sosyo-Ekonomik Gelişmişlik Sıralaması Araştırması (SEGE-2011)". Ankara: Bölgesel Gelişme ve Yapısal Uyum Genel Müdürlüğü.

TÜIKK (2018). "Bölgesel İstatistikler". Türkiye İstatistik Kururmu: https://biruni.tuik.gov.tr/bolgeselistatistik/tabloOlustur.do (01.03.2018)

URAK (2016). "İllerarası Rekabetçilik Endeksi". İstanbul: Uluslararası Rekabet Arastırmaları Kurumu Derneği. 